\title{
The Formation of the Guide-interpreter to Work with Deafblind People
}

\author{
Raffaela de Menezes Lupetina \\ Education at the State University of Rio de Janeiro (UERJ) \\ Teacher at Instituto \\ Benjamin Constant, Brazil \\ Instituto Benjamin Constant, Brazil \\ Tel: 055-21-98836-6561_E-mail: raffalupetina@gmail.com
}

Received: June 13, 2017 Accepted: July 30, 2017 Published: August 1, 2017

doi:10.5296/jse.v7i3.11392 URL: https://doi.org/10.5296/jse.v7i3.11392

\begin{abstract}
This paper aims to present the main characteristics of the professional who works directly with individuals with acquired deafblindness: the guide-interpreter, in addition, to address the differences between deafblindness and multiple disabilities and explain the characteristics of congenital deafblindness and acquired deafblindness. In this study, a research was conducted with professionals who underwent the guide-interpreter training course in 2016. Fourteen professionals who completed the course participated in the study. In this research, we seek to understand: the profile of individuals who seek and perform the guide-interpreter training course; the main forms of communication used with the deafblinds during the course and whether these newly-trained guide-interpreters have been professionally inserted as a guide-interpreter in the job market. The results contemplate that most of the professionals already work using sign language, but during the training course the form of communication most used with the deafblinds was the extended speech.
\end{abstract}

Keywords: Deafblind, Guide-interpreter, Accessibility. 


\section{Introduction}

This article seeks to bring contributions to the field of deafblindness and to emphasize the importance of the role of the guide-interpreter in the social life of the subject with acquired deafblindness. Throughout this text concepts about this disability and references about the role of guide-interpreter will be presented, in addition to charts with data elaborated from questionnaires completed by individuals who carried out the training course for guide-interpreter.

\subsection{Purpose of the study}

The purpose of this study is mainly to demonstrate the importance and specificity of the professional guide-interpreter who acts directly with deafblind people, in addition to addressing the differences between deafblindness and multiple disabilities and explaining the characteristics of congenital deafblindness and acquired deafblindness, aiming to contribute to future studies.

\subsection{Objectives of the study}

A) Understand the profile of the people who have taken the training course for guide-interpreter;

B) Know the main forms of communication used with the deafblinds during the course;

C) Find out if these interpreter guides, after graduating, worked professionally with deafblind people.

First, it is necessary to conceptualize deafblindness. Masini (2002) presents a definition of deafblindness, which explains that the deafblinds usually present some visual and/or auditory residue and, in some cases, we have total deafblinds, who have no auditory nor visual vestiges. It is important that these residues are considered and stimulated, always verifying their functionalities.

Deafblindness is a combination of hearing and visionloss. In fact, a deafblind person is sometimes totally deaf and blind, but very often he/she is deaf with some sight or blind with some hearing. Some deafblind people have auditory and visual memory. [...] Being deafblind does not mean, typically, that the person suffers from a total loss in both senses - hearing and sight. Individuals very often still have residual functions in one or both senses (p.119, 122).

More important than trying to classify or verify the intensity of sensory losses, is to seek to understand the functionality of the residue, because it is from the functionality that a rehabilitation program or educational proposal suitable for each deafblind can be designed. In addition, it is relevant to understand the importance of deafblind spelt as a single word. According to Lagati (1995):

Deafblindness is a condition that presents other difficulties beyond those caused by blindness and deafness. The term hyphenated indicates a condition that would comprise the difficulties of deafness and blindness. The word without hyphen would indicate a difference, a unique condition, and the impact of double loss is multiplicative and not additive (p.306). 
Previously, the spelling contained a hyphen, and accepting the words deafblind or deafblindness all together, instead of the hyphenated word "deaf-blind" or "deaf-blindness" is to recognize the complexity involving a deafblind person and to accept her/him as a singular person. The author argues that deafblindness brings limitations beyond the sensorial losses of hearing and vision, and that by unifying the two words we contribute to the recognition and legitimacy of the disability.

Another key point is to understand the distinction between the deafblind and the multiple disabled person. Common sense tends to think and refer to the deafblind as a person with multiple disabilities, but they are and should be considered distinct disabilities. This division is fundamental, because being considered deafblind, the individual will have access to the appropriate professional for her/him: the mediator instructor if she/he is a congenital deafblind or the guide-interpreter if she/he is an acquired deafblind.

Table 1. Differences between multiple disabilities and deafblindness

\begin{tabular}{|c|c|c|}
\hline & Multipledisabledperson & Deafblind \\
\hline \multirow[b]{2}{*}{ Possibilities } & $\begin{array}{l}\text { Hearing impairment plus another } \\
\text { impairment }\end{array}$ & Hearingand visual impairment \\
\hline & $\begin{array}{l}\text { Visual impairment plus another } \\
\text { impairment }\end{array}$ & $\begin{array}{l}\text { Hearing and visual impairment } \\
\text { plus another impairment }\end{array}$ \\
\hline Explanation & $\begin{array}{l}\text { The multiple disabled person has only } \\
\text { one of the sensory impairments, added } \\
\text { to another impairment. Most often the } \\
\text { multiple disabled person has an } \\
\text { intellectual disability associated. }\end{array}$ & $\begin{array}{l}\text { The deafblind will always } \\
\text { have both } \\
\text { impairments jointly (visual } \\
\text { and hearing). }\end{array}$ \\
\hline
\end{tabular}

Table designed by the author from the record.

From Table 1 it becomes more noticeable the understanding of the main differences between the two disabilities. The multiple disabled person has only one sensory impairment (visual impairment, for example) added to another impairment without being sensorial (intellectual, for example). Meanwhile, the deafblind necessarily has two associated sensory losses (vision and hearing), and there may be another impairment added to this picture. In Canada, the term "deafblind-plus" is used when referring to the deafblind who has another impairment other than deafblindness, such as: deafblindness with autism.

It was only in the year 2005 that deafblindness was officially separated from multiple disability in the Census. The Brazilian Census is conducted by the Brazilian Institute of Geography and Statistics (IBGE).

According to the School Census MEC/ INEP - Ministry of Education/ Anísio Teixeira National Institute of Educational Studies and Researches, referring to the number of students with deafblindness enrolled in the years 2007 to 2013 in basic education (which includes elementary school, middle school and high school) we have: 


\section{Macrothink}

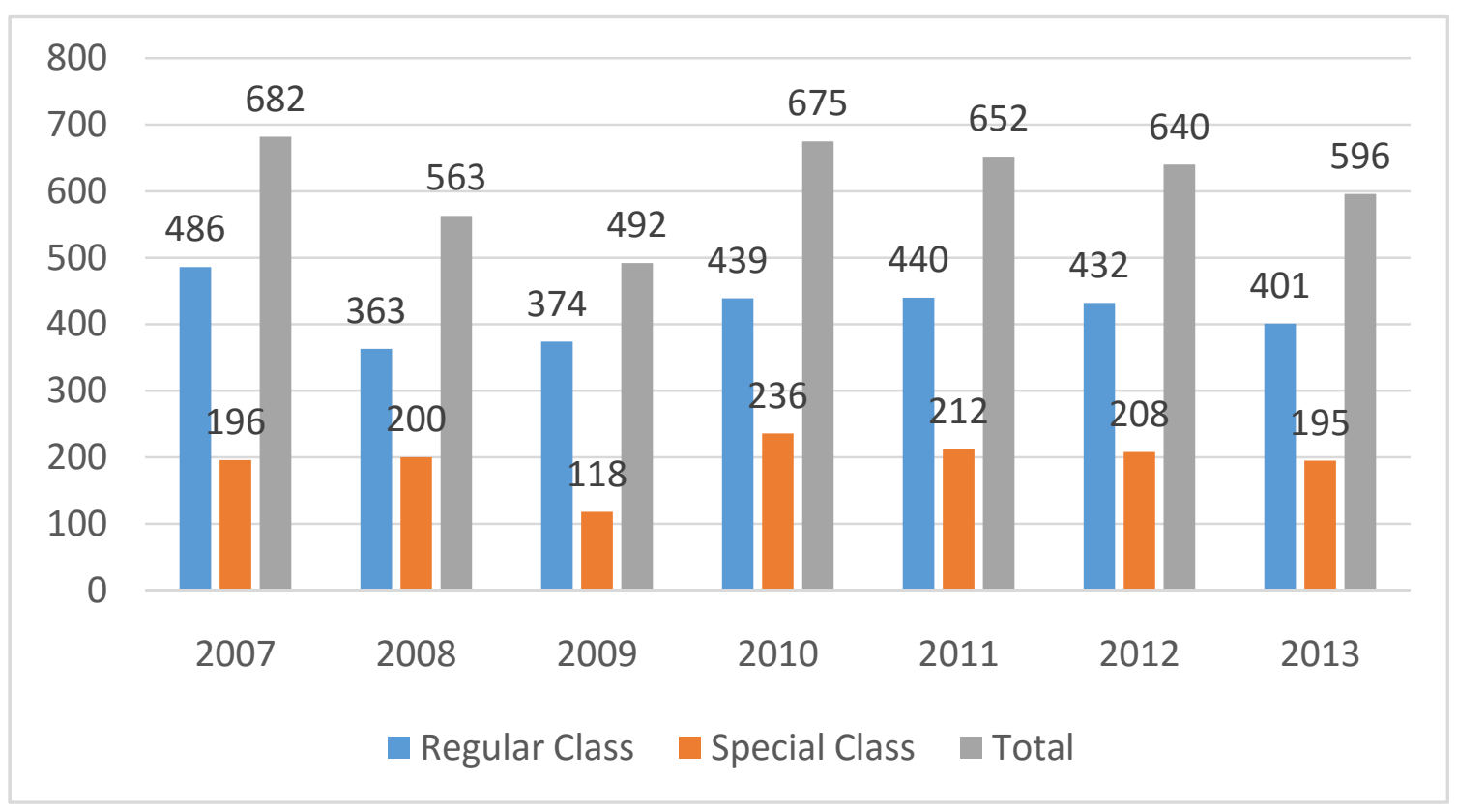

Chart 1. Students with deafblindness enrolled in Basic Education between 2007 and 2013

Chart prepared by the author based on the data collected in the MEC / INEP School Census.

From the data collected in the MEC / INEP School Census it is possible to notice that the number of deafblind students enrolled in Basic Education in the time span from 2007 to 2013 is higher in the regular classes than in the special classes. In the regular class, the number ranged from 363 to 486 enrolled, while in the special class it ranged from 118 to 236 students.

Regarding the total number of deafblind students enrolled between 2007 and 2013, this total represents the sum of the enrollments in the regular class and the special class, varying between 492 and 682. The year of 2009 was the one that had less enrollments and the year of 2007 the one which had more. It is important to note that the number of deafblind students enrolled does not really reflect the number of students who have followed or completed Basic Education, there are possibilities ofevasion or interruption of studies for a variety of reasons, one of which being the lack of teacher preparation and of the school institutions in receiving students with deafblindness.

It is also important to bring the concepts of the International Classification of Functioning, Disability and Health (ICF), which clarifies the issue of functionality and considers that a disability may interfere in the participation in activities and may lead to limitation of activities and/or restrictions on participation. In the case of deafblindness:

Table 2. Limitation and restriction on deafblindness

\begin{tabular}{|l|l|}
\hline \multicolumn{1}{|c|}{ Limitationonactivity } & \multicolumn{1}{c|}{ Restrictiononparticipation } \\
\hline $\begin{array}{l}\text { Difficulty in getting around in unfamiliar } \\
\text { environments }\end{array}$ & Difficulties in communicating with others \\
\hline
\end{tabular}

Table designed by the author from the record. 


\section{Mll Macrothink}

The ICF defines activity limitation and participation restriction as: "Activity limitations are difficulties that an individual may encounter in performing activities. Restrictions on participation are problems that an individual may experience in involvement in real life situations "(2004, p.16).

In this sense, the examples presented in Table 2 demonstrate one of the limitations that the deafblind faces in daily life, that is, the difficulty of locomotion, and one of the restrictions of participation that the deafblind person experiences, the difficulty of communication.

After this introduction, it is essential to understand the differences between congenital deafblindness and acquired deafblindness, since these terms indicate many characteristics and specificities of the deafblind person.

\section{Congenital deafblindness and acquired deafblindness}

Understanding the differences between congenital and acquired deafblindness is important in the field of deafblindness, of special education and for public in general. Some researchers refer to the congenital deafblind as pre-linguistic or pre-symbolic, and to the acquired deafblind as post-linguistic or post-symbolic. In this text, we will use the congenital and acquired nomenclature. The following table shows the main differences:

Table 3. Differences between congenital deafblindness and acquired deafblindness

\begin{tabular}{|c|c|c|c|}
\hline & Congenital deafblindness & & Acquireddeafblindness \\
\hline Characteristics & $\begin{array}{l}\text { The child who is born or acquires deafblin } \\
\text { acquiring a language (Sign Languag } \\
\text { Language). }\end{array}$ & $\begin{array}{l}\text { idness before } \\
\text { or Oral }\end{array}$ & $\begin{array}{l}\text { Children, young people and } \\
\text { adults who acquire } \\
\text { deafblindness } \\
\text { acquiring a language (Sign } \\
\text { Language or } \\
\text { Language). }\end{array}$ \\
\hline auses & \begin{tabular}{|l|l|} 
& $\begin{array}{l}\text { In the } \\
\text { perinatal } \\
\text { period: } \\
\text { prematurity; } \\
\text { lack of }\end{array}$ \\
In the prenatal stage: & oxygen and \\
congenital rubella;congenital & ingestion of \\
syphilis; AIDS;Toxoplasmosis & ototoxic \\
and cytomegalovirus & antibiotics.
\end{tabular} & $\begin{array}{l}\text { Syndromes: } \\
\text { CHARGE } \\
\text { syndrome } \\
\text { and } \\
\text { folfram or } \\
\text { Diamoad } \\
\text { syndrome. }\end{array}$ & $\begin{array}{l}\text { Accidents; Stroke; Diabetes } \\
\text { Mellitus; Refsum } \\
\text { Disease; Meningitis;Usher } \\
\text { Syndrome; Barder-Biedl } \\
\text { syndrome;Hallgreen } \\
\text { syndrome;Flynn-Aird } \\
\text { Syndrome and Cockayne } \\
\text { Syndrome. }\end{array}$ \\
\hline
\end{tabular}

Table developed by the author from the reading of Cader-Nascimento e Costa (2010).

From Table 3, the acquisition time of deafblindness clearly defines whether it is congenital or acquired. If this is from birth or was acquired prior to the development of a language (oral or signs), the individual is a congenital deafblind. If the acquisition was after the language development, the subject is an acquired deafblind. It is important to note that when the individual becomes deafblind before beginning to speak or signal, he falls into the category: 
congenital deafblind.

A relevant data is the increase in the deafblind population among the elderly, it is becoming very common for the older population to develop deafblindness. Poor hearing and poor vision in the elderly is considered deafblindness. There are cases of elders who were deaf but did not learn Sign Language (they communicated only through home signs) and with aging they acquired visual impairment and became deafblind. And now? How to communicate? This is a question that needs to be considered, since the elderly deafblind population is becoming significant. According to the VI International Forum on Deafblindness and Multiple Sensory Disability and II Ibero-Latin American Meeting in the area of deafblindness and multiple sensory disabilities, which occurred in May 2016 at the University of São Paulo (USP), the largest portion of deafblinds currently are over 40 years old.

\subsection{Congenital deafblindness}

There are some actions that can be developed with the congenital deafblind to develop their perception and autonomy. According to the MEC 2006 document developed by Cader-Nascimento that addresses the knowledge and practices of inclusion in early childhood education, the activities can be: use of reference objects; tactile clues; communication notebook; calendar; natural gestures; adapted signs; body movements and easy expression. Always allowing the deafblind child's touch to explore the environment and the facial expressions of the teacher or mediator instructor.

On the calendar, you can hang a diaper and other objects that anticipate an action, changing the diaper or brushingthe child's teeth, for example. The reference objects can be a "cutlery" at the entrance of a room, anticipating the activity that will be performed. Both the calendar and the object of reference will have as their main function to anticipate to the congenital deafblind what will happen next. The authors Cader-Nascimento and Costa (2010), reinforce the importance of anticipation in the development of language of the congenital deafblind: "[...] we value the movement with and without support, the communication of the child with the environment, the structure development and the organization of time. It is sought to avoid that events be always unforeseeable for the deafblind "(p.44).

In the work with congenital deafblinds, Cader-Nascimento $(2006,2010)$ indicates Van Dijk's co-active approach. Dijk (1968) conducted a research with children with congenital rubella and developed a co-active approach that emphasizes body movement. He proposes six stages of development of the symbolic language of the deafblind child, these are: nutrition; resonance; co-active movement; non-representative reference; imitation and natural gesture.

The reference objects and actions that seek to inform and anticipate to the deafblind child what will happen, as well as Van Dijk's co-active approach, are essential to contribute to the development of the congenital deafblind. According to Cader Nascimento (2006):

The information of the world must reach the child in a structured and systematized way, so that she/he can begin to build her/his own world. This procedure will aid in the construction of knowledge as a whole, since the lack of basic sensory information such as vision and hearing 
mean that each child, when exposed to a stimulus, can absorb only part of that information. Only the repetition of stimuli in meaningful contexts can ensure that she/he will be able to assimilate the stimulation as a whole (p. 13).

Therefore, the work of teachers and the family in the education and development of the congenital deafblind is essential for her/his development. In dealing with a deafblind child, the tactile stimulation and the repetition of the actions are essential, so that she/he develops the assimilation and accommodation of the learning.

\subsection{Acquired deafblindness}

In the acquired deafblindness, the individuals developed some form of previous communication (oral or signalized) and later became deafblind. As seen on Table 3, acquired deafblindness may be due to several syndromes and diseases. According to Gomes (2016):

There are people among the acquired deafblind who have visual and hearing residue, but whose combination of these losses interfere in the performance of their daily life activities. If on the one hand we consider the fact that these people had the opportunity to contact and develop a language, whether oral or sign language, that is, that they have a symbolic communication system that allows them to maintain social relations; on the other hand, the psychological impact on these individuals may be so profound that they will need time and special attention to adapt their sensory system to this new condition (p.31).

In this sense, the acquired deafblinds, even having a prior communication system, suffer a great psychological impact, which can interfere in the formation of a new identity, in the process of resocialization and in the acceptance of the deafblind condition.

Among the main causes of acquired deafblindness, the most common is Usher Syndrome. It is appropriate to present the three existing types of Usher Syndrome:

Table 4. The Three Types of Usher Syndrome

\begin{tabular}{|c|c|c|}
\hline Type 1 & Type 2 & Type 3 \\
\hline $\begin{array}{l}\begin{array}{l}\text { Severe or } \\
\text { neurosensory } \\
\text { bilateral, congenital. } \\
\text { deafness, }\end{array} \\
\begin{array}{l}\text { Alteration or absence of } \\
\text { vestibular } \\
\text { leading to } \\
\text { problems. } \\
\text { balance }\end{array} \\
\begin{array}{l}\text { Initial } \\
\text { encompasses } \\
\text { blindness } \\
\text { childhood or adolescence, } \\
\text { and may be progressive. }\end{array}\end{array}$ & $\begin{array}{l}\text { Mild to moderate hearing } \\
\text { impairment, bilateral and } \\
\text { symmetrical, } \\
\text { progressive. } \\
\text { Normal vestibular } \\
\text { function. } \\
\text { At the end of childhood or } \\
\text { adolescence, scotomas } \\
\text { (blind spots) appear, that } \\
\text { lead to blindness in } \\
\text { adulthood. }\end{array}$ & $\begin{array}{l}\text { The child is born with good } \\
\text { hearing or mild to moderate } \\
\text { hearing loss, which accentuates } \\
\text { after ten years or more. } \\
\text { Night blindness and presence of } \\
\text { scotomas from infancy to } \\
\text { adulthood. The person is } \\
\text { considered legally blind at the } \\
\text { beginning or middle of adulthood. }\end{array}$ \\
\hline
\end{tabular}


Table designed by the author from the record.

As shown on Table 4, in all three types of Usher Syndrome there is impairment of the senses of sight and hearing, but at different levels and ages. The syndrome corresponds to a genetic disorder that mainly affects hearing, vision and balance. According to Deafblind International, about 400,000,000 people worldwide are affected by Usher Syndrome (data updated in 2016).

In an initial contact with the individual with acquired deafblindness in the school environment or in the rehabilitation care, there are some questions that may help to understand the profile of the deafblind, for example: How old did she/he start to lose vision? How old did she/he begin to lose hearing? Did she/he stay in the hospital too long? Was there encouragement and support from the family? Doesshe/he have any health issues (diabetes, degenerative disease, etc.)? Are there remnant residues?

As for the appropriate form of communication for each individual with acquired deafblindness, it will depend on the form of communication that she/he used before. According to Grupo Brasil (2012):

If a person acquires deafblindness, the new form of communication will serve as receptive communication, because if before the deafblindness, she/he was a user of an oral language like the Portuguese language, probably this will be maintained and she will respond with the voice, that is, her/his expressive communication will continue through the oral Portuguese language. While the person who, before becoming deafblind, was a LIBRAS (Brazilian Sign Language) user, and because of the deafblindness, she/he will have a new form of receptive communication, in expressive communication she/he will continue to use LIBRAS (p. 49).

Therefore, it becomes important for the guide-interpreter to know the form of communication used by the deafblind person prior to acquiring the disability. When referring to the use of the Portuguese Language, the same rule would apply to the use of the English Language or any other. Likewise, when referring to LIBRAS - Brazilian Sign Language, it would also apply to ASL - American Sign Language, or any other sign language. The key is to preserve the most comfortable form of communication for the deafblind.

\section{The importance of the professionals working with the deafblind}

According to Watanabe (2012), when it comes to the person with acquired deafblindness, the indicated professional is the guide-interpreter. Whereas, when dealing with people with congenital deafblindness or with multiple disabilities, the ideal is the professional denominated mediator instructor, because in addition to dominating the different forms of communication, specific resources and alternative forms of communication will be necessary, since the congenital deafblind and the person with multiple disabilities may have cognitive impairments that influence how they contact others.

To understand more clearly the role of the guide-interpreter it is important to understand the main differences of this professional from the others: 
Table 5. Differences and attributions of each professional

\begin{tabular}{|l|l|l|l|}
\hline \multicolumn{1}{|c|}{ Professional } & \multicolumn{1}{|c|}{ Acts with } & $\begin{array}{l}\text { Carries out the } \\
\text { description }\end{array}$ & \multicolumn{1}{c|}{ Prerequisites } \\
\hline Guide-Interpreter & $\begin{array}{l}\text { People with acquired } \\
\text { deafblindness }\end{array}$ & $\begin{array}{l}\text { Auditory, } \\
\text { visual } \\
\text { tactile }\end{array}$ & and \\
\hline Sign Language and Braille
\end{tabular}

Table adapted from Watanabe (2012).

From Table 5 it is possible to perceive, at first, the difference of the target audience of each professional. The guide-interpreter (GI) will work with people with acquired deafblindness, that is, they have become deafblind after establishing a form of communication, hence the need to master the Sign Language and the Braille System. The mediator instructor, in turn, will deal directly with people with congenital deafblindness, who were born deafblind or who have become deafblind before communicating, in addition to people with multiple disabilities, in which case, in addition to Sign Language and Braille System, it is required the knowledge of Alternative Communication, to enable the communication of the deafblind or multiple disabled child. While the sign language interpreter translator (TILS) will work with deaf people using Sign Language.

In relation to the mediator instructor, according to Godoy (2014):

The professional mediator instructor acts with people with pre-linguistic or congenital deafblindness, he contributes to the process of teaching-learning as a communication link, mediating between the learner and the world around her/him, enabling her/him to communicate with her/his environment in order to receive reliable information (p.7).

Based on this contextualization explaining the main differences between the professionals who work with the deafblind, mediator instructor and guide-interpreter, it is necessary to bring more specific definitions about the guide-interpreter, who is the focus of this text.

\subsection{Main characteristics of the guide-interpreter in the performance with deafblinds}

The guide-interpreter is the appropriate professional to accompany the acquired deafblind and the mediator instructor is the one to act with the congenital deafblind. In this text, we will focus on the role and training of the guide-interpreter (GI), for this, we performed a field work through the application of structured questionnaires with people who completed the training course in GI in the year 2016. Costa (2013) defines the GI as:

The guide-interpreter is the person who is knowledgeable in the language or communication system of both the person with the deafblindness and his or her interlocutor, communicates 
messages expressed by one to the other in a textual and objective manner, making communication possible. She/he should contextualize the messages, providing the relevant visual information so that they are properly understood and guide the person with deafblindness in the movements, providing him with security when she/he asks for it, that is, necessary (COSTA, 2013, p.202).

The guide-interpreter is an essential professional in the daily life of the acquired deafblind, mainly regarding communication and locomotion. Many people are unaware of the forms of communication of the deafblind (Tactile Sign Language, Sign Language in reduced field, Tadoma etc.) and therefore the presence of the GI is essential to mediate this conversation between the deafblind and the other(s). In relation to locomotion, the presence and assistance of the GI is indispensable, because it will transmit to the deafblind information regarding space, visual objects, paths, people, and other possible interlocutors.

According to Grupo Brasil (2005), the guide-interpreter has three main responsibilities: (1) to transmit messages in the form of communication used by the person with acquired deafblindness; (2) make the visual, auditory and tactile description of people, environments and objects; and (3) guide the deafblind according to sighted guiding techniques and of orientation and mobility.

The sighted guide is the person who guides a visually impaired person, with deafblindness or multiple sensory disability, to walk around in various places allowing the person with a disability to place his or her hand on the guide's elbow or shoulder.

In the transmission of the message, the GI allows the communication of the deafblind with the other and, in addition to the main form of communication used by the deafblind, the guide-interpreter can use the haptic communication to transmit more information (from the environment, people) to the deafblind. This form of communication has the function of conveying information such as: description of the environment; short messages; messages of orientation and mobility, and emotional expressions.

Haptic communication can be performed on the back, thigh, hand or where it is best for the deafblind, and it is used to describe a room, or another location, in addition to the movements of people. The best place for the guide-interpreter to perform haptic communication will depend on the previous combination with the deafblind.

This form of communication can be done by a single guide-interpreter, who will perform the main communication allied to haptic communication, as well as two guide-interpreters, one with the main communication (for example, Tactile Sign Language) and the other with haptic social communication. It is necessary to keep in mind that haptic social communication is usually a complement to the main form of communication.

The Brazil Group (2012) explains one of the functions performed by the guide-interpreter. The trained GI can convey the message, contextualize and guide the person with deafblindness:

In the transmission of the message, the interpreter guide can perform a transliteration or interpretation work. In the case of transliteration, the guide-interpreter receives the message in 
a given language and transmits it to the deafblind person in the same language, but using the form of communication accessible to that person, for example, the guide interpreter hears the message in Portuguese and transmits it in tactile braille. Unlike the interpretation situation, when the guide-interpreter receives the message in one language and must transmit it in another language, for example, the guide interpreter hears the message in Portuguese and transmits it in tactile LIBRAS (Brazilian Sign Language) (GRUPO BRASIL, 2012 , P.51).

Therefore, when translating the Portuguese language message into tactile braille or from Portuguese to Tadoma, the guide-interpreter is transliterating (transmitting the message in the same language). While performing the transmission of the Portuguese language message to Sign Language, the guide-interpreter is performing an interpreting service because it involves two distinct languages in the same process.

The role of the guide-interpreter also involves ensuring the safety of people with deafblindness in locomotion, whether on the street, in public or private establishments, in public transportation, in banks, among others. The person with deafblindness needs the proper accompaniment of the guide-interpreter, who, through orientation and mobility sighted guiding techniques, is able to guide the deafblind.

From this perspective, it is worth emphasizing the importance of proper training for the qualification of the guide-interpreter. According to Godoy (2014):

To perform the role of guide-interpreter the professional needs to present specific complementary training, to have knowledge of techniques and skills of different forms of communication so that she/he can transmit the messages to the person with deafblindness, facilitating the communication and interaction with the environment, favoring the displacement and mobility in all environments, that is, from the narrowest to the widest (p.7).

The results of a field survey conducted with professionals who completed this supplementary guide-interpreter training course to deal with acquired deafblindness will be presented below.

\subsection{Results of questionnaires applied to guide-interpreters}

This subitem will present the results of the questionnaires applied to individuals who undertook the training course for guide-interpreter in 2016, to deepen the knowledge about deafblindness and, for the most part, to act professionally with deafblind people.

This course is part of the Bridges and Crossings Project of the Brazil Group for Supporting the Deafblind and the Multiple Sensory Disabled Person. Grupo Brasil is a nongovernmental organization (NGO) founded in 1999 in São Paulo - Brazil with the aim of disseminating knowledge and continuous training of professionals, family members and people with deafblindness. This course provides theoretical and practical foundation enabling the professional to work with deafblind people.

The applied questionnaire was composed of five questions seeking to understand: (a) the profile of the individual who carried out the training course for guide-interpreter; (B) the main forms of communication used with the deafblinds during the course; and (c) whether these trained guide-interpreters have performed professionally with the deafblind. 


\section{Ml Macrothink}

The questionnaire corresponds to the closed format. According to Amaro; Póvoa and Macedo (2005), this type of questionnaire facilitates the treatment and analysis of the information, requiring less time for the researcher, besides being more objective and requiring less effort from the research participants. Still according to Amaro; Póvoa e Macedo (2005):

The application of a questionnaire allows to collect a sample of the knowledge, attitudes, values and behaviors. Thus, it is important to consider what you want and how you will evaluate [the results], being necessary to have rigor in the selection of the questionnaire type to be applied, to increase its credibility (p.6).

The questionnaire application advantages according to Boni and Lent (2005) are:

Some of the main advantages of a questionnaire is that it is not always necessary the presence of the researcher for the informant to answer the questions. In addition, the questionnaire can reach several people at once, getting many data and being able to cover a wider geographic area if this is the objective of the research. It also ensures greater freedom of responses because of anonymity, avoiding potential biases of the interviewer. Generally, through the questionnaire, one can obtain fast, accurate answers (p.7)

In this sense, we opted for the questionnaire as most of the participants are residents of other states of Brazil, and through the questionnaire method, it was possible to be sent by e-mail and responses were received at a faster time, facilitating the progress of the study. It is important to note that the participants were informed that their names would not be disclosed, ensuring their anonymity.

The questions contained in the questionnaire were: (1) Before the guide-interpreter course have you had contact with deafblinds? (2) If you have contact with deafblinds, are most of them congenital deafblind or acquired deafblind? (3) Before the guide-interpreter course have you worked using Sign Language? (4) During the course, which form of communication was the most used? Tactile Sign Language; Sign Language in reduced field; Tadoma; Amplified Speech; Another form of communication (5) Upon completion of the course, have you already had professional experience as a guide-interpreter?

Through these questions we can understand and reflect on the process of training of guide-interpreters who will work professionally with acquired deafblinds.

The questionnaire was sent to fifteen people, with the return of fourteen, a person did not respond to the questionnaire. Of the fourteen respondents, thirteen are women and only one man. From the responses, it was possible to prepare the following charts: 


\section{Macrothink}

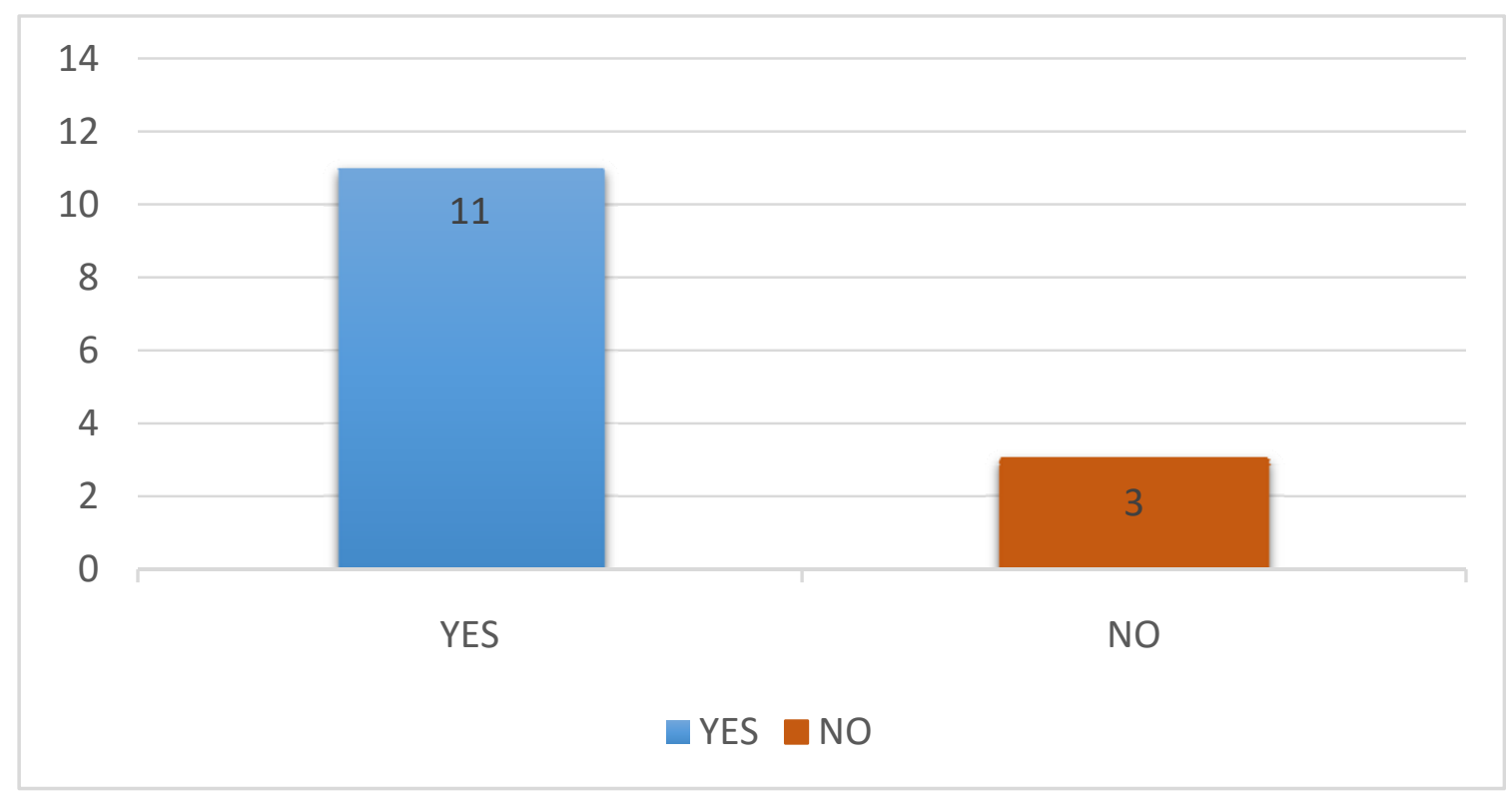

Chart 2. Contact with deafblinds before the interpreter-guide course

Chart made by the author from the answers of the questionnaire.

Chart 2 shows the number of professionals who had had contact with deafblinds prior to the guide-interpreter training course. As shown, most had had some contact with deafblinds, which reflects one of the reasons that led these individuals to seek the training course.

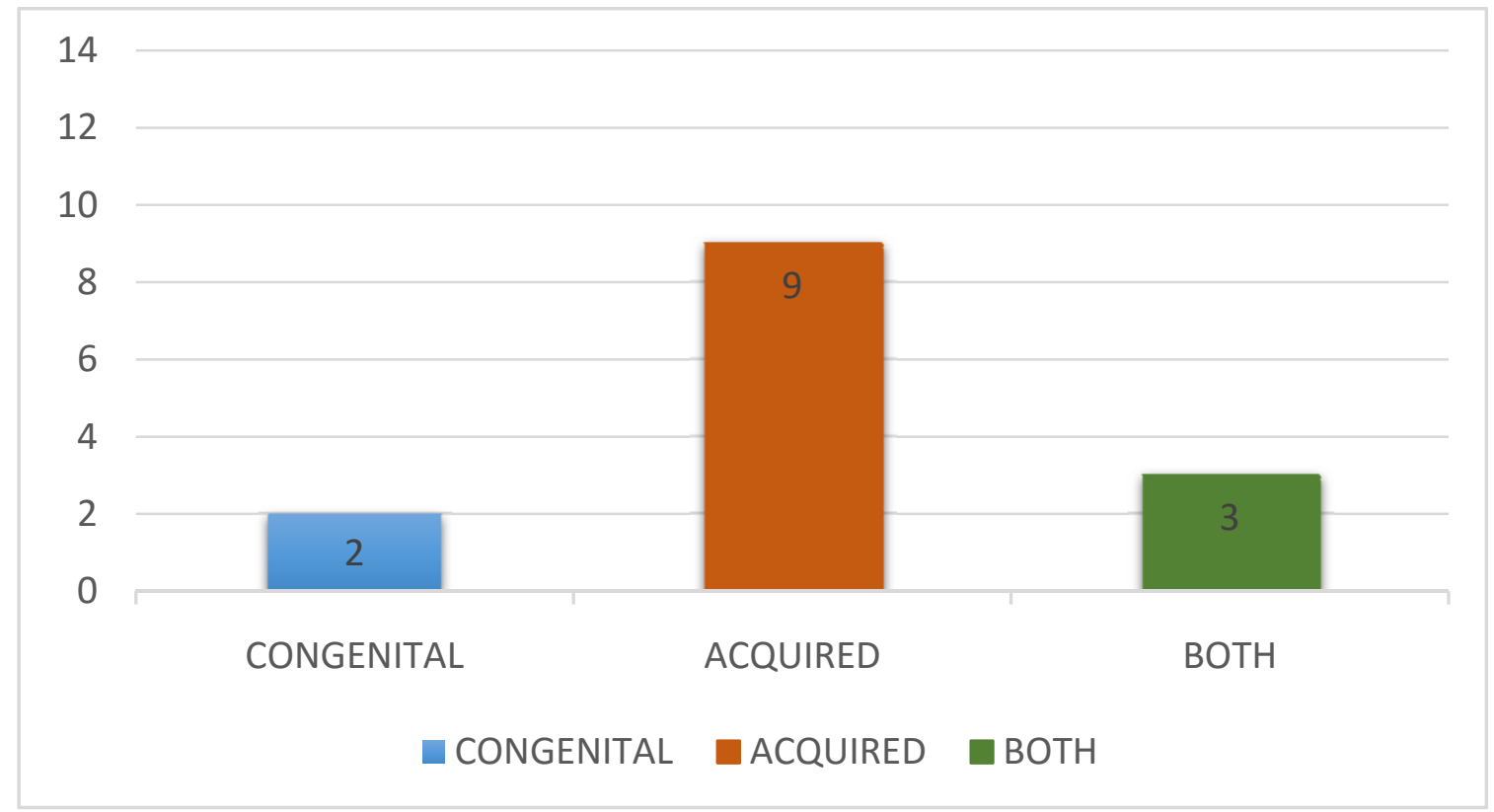

Chart 3. Profile of the deafblind: congenital or acquired

Chart made by the author from the answers of the questionnaire.

Chart 3 was drawn from the question: "If you have contact with deafblinds, are most of them congenital deafblinds or acquired deafblinds?", that is, the question aimed to find out if the professionals had contact with congenital deafblind, acquired or both. As noted in the chart, most established contact with acquired deafblinds. 


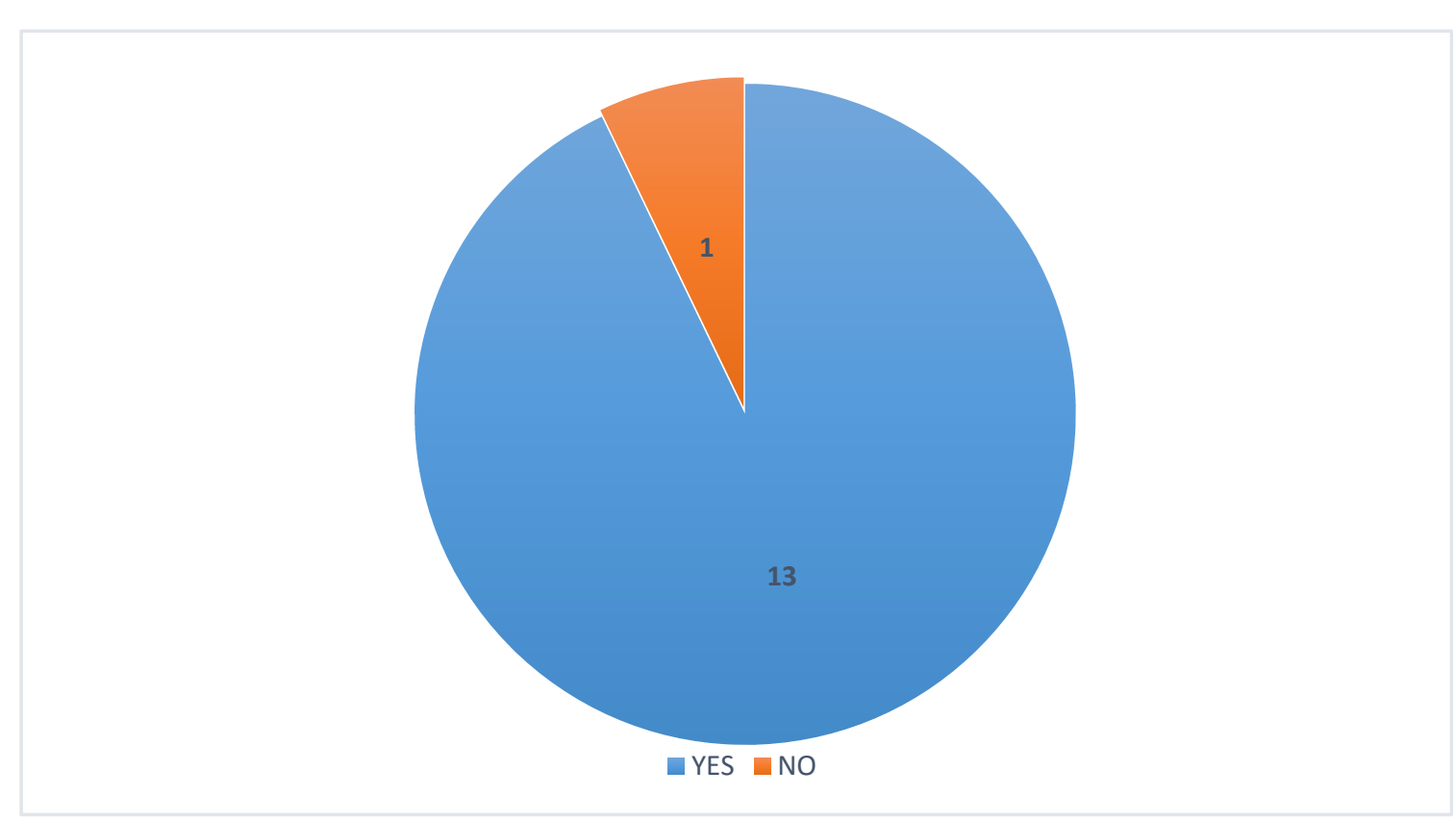

Chart 4. Use of Sign Language before the guide-interpreter course

Chart made by the author from the answers of the questionnaire.

During the research, it was revealed that most people looking to specialize themselves to work as a deafblind guide-interpreter, are people already working with Sign Language and with deaf people, which demonstrates knowledge and experience in the field of special education and interest in working with deafblinds. From Chart 4, it is confirmed that the clear majority already used Sign Language prior to the course.

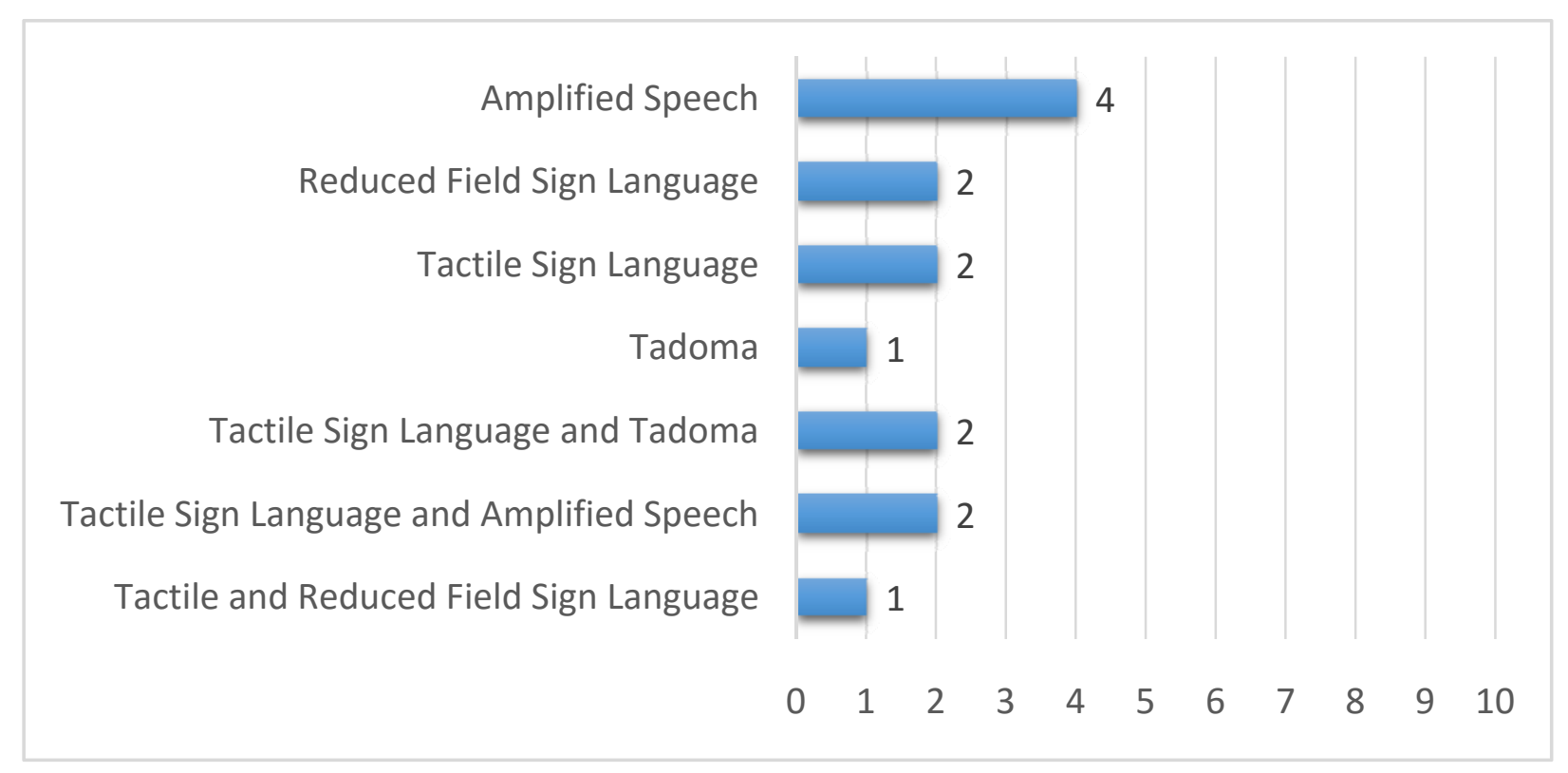

Chart 5. Form of communication most used during the guide-interpreter training course Chart made by the author from the answers of the questionnaire.

During the guide-interpreter training course, it is required to practice 80 hours of internship, to 
prove the practical part, combined with the theory, aimed at the training of the professional. Clearly, the contact with the largest possible number of communication forms would be ideal, to provide a more complete training.

In carrying out the questionnaire for the preparation of Chart 5 , the following question was made: "During the course, what form of communication was the most used?", as options, the following answers were given: Tactile Sign Language; Reduced Field Sign Language (for the deafblind with visual residue); Tadoma; Amplified Speech; or some other form of communication.

As it can be noted, Amplified Speech was the most widely used means of communication during the course, and some had the opportunity to work with more than one form of communication. However, among the total of fourteen respondents, four used only Amplified Speech as a form of communication.

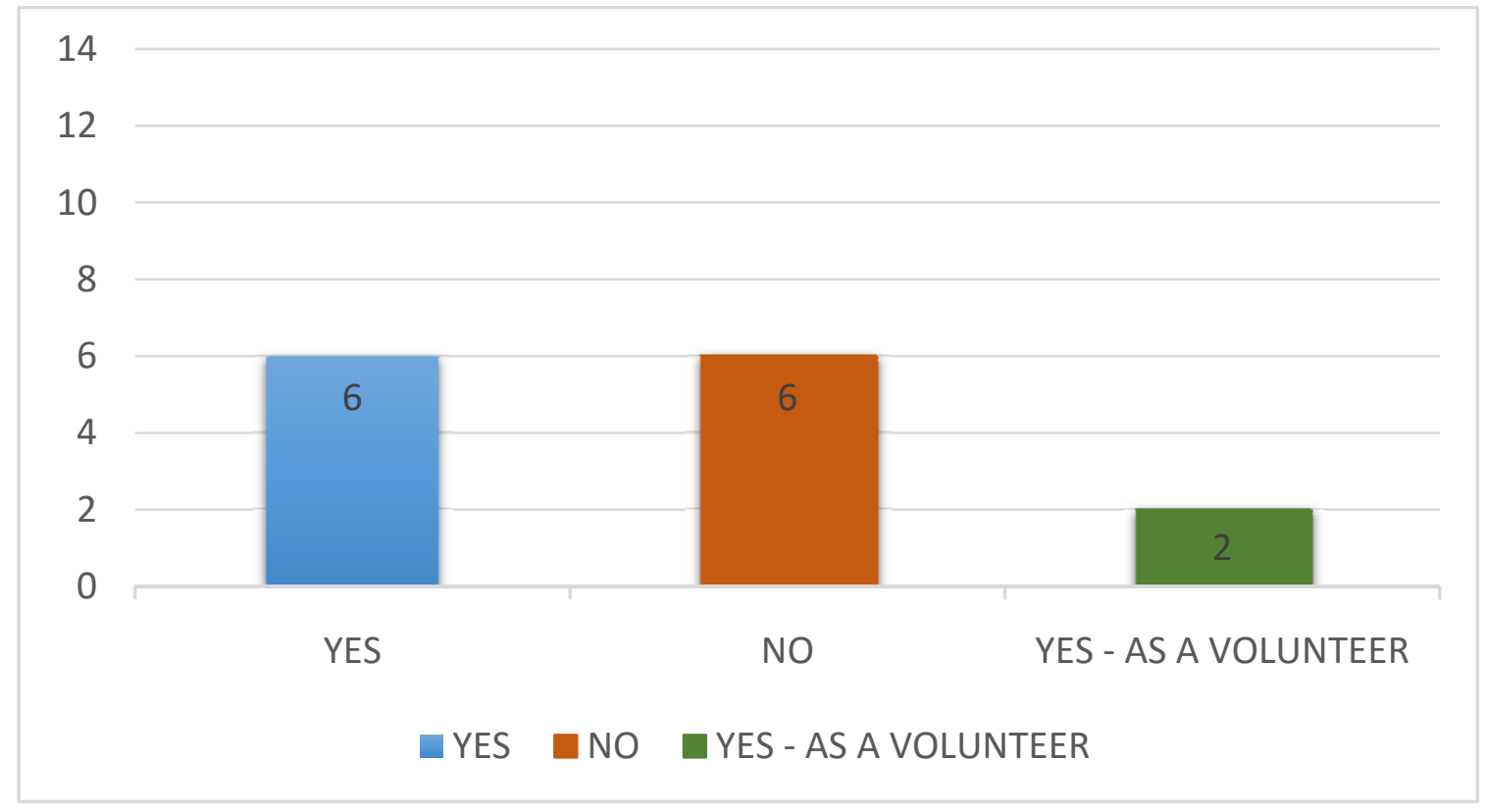

Chart 6. Professional Acting as a guide-interpreter after completing the course

Chart made by the author from the answers of the questionnaire.

Of the total of fourteen respondents, eight worked professionally as a guide-interpreter after the completion of the course, six remunerated and two voluntarily. The other six participants did not work as a GI after completion of the course.

\section{Recommendations for Future Research}

From the realization of this study, we can see the importance of knowing the characteristics of deafblindness and the specificities of congenital and acquired deafblindness. In addition, it is worth highlighting the importance of training and of the professional guide-interpreter in the education and daily life of people with deafblindness.

It should be noted that this study aims to contribute to the field of special education and the area of deafblindness, since the latter is still scarce in publications, especially if we compare to the quantitative of publications related to other disabilities. 
When conducting a survey in the Bank of Theses and Dissertations of the Capes Portal(bancodeteses.capes.gov.br) over a time span of ten years (2006-2016) we found: 453 researches on hearing impairment; 879 researches on visual impairment; 442 researches on physical disability; 582 researches on intellectual disability; 724 research on autism and only 25 researches on deafblindness, which shows a small quantity of researches in the area.

Therefore, it is expected that this research will bring about other researches and will collaborate with researchers in the field of special education. Deafblindness needs a closer look in Brazil and in the world, because it is a disability that requires advances in resources, investment, scientific production and, specially, caring, affection and human rights.

\section{References}

AMARO, Ana; PÓVOA, Andreia; MACEDO, Lúcia. (2005). A arte de fazer questionários. Metodologias de investigação em educação. Departamento de química. Faculdade de Ciências da Universidade do Porto, 02-10.

BONI, Valdete; QUARESMA, Silvia Jurema. (2005). Aprendendo a entrevistar: como fazer entrevistas em Ciências Sociais. Em Tese -Revista Eletrônica dos Pós-Graduandos em Sociologia Política da UFSC, 2(1), 68-80.

CADER-NASCIMENTO, Fatima Ali Abdalah Abdel; COSTA, Maria da Piedade Resende da. (2010). Descobrindo a surdocegueira: educação e comunicação. São Carlos: EdUFSCar, 07-78. https://doi.org/10.7476/9788576003717

CADER-NASCIMENTO, Fátima Ali Abdalah Abdel. (2006). Educação infantil: saberes e práticas da inclusão dificuldades de comunicação e sinalizaçãosurdocegueira/múltipla deficiência sensorial. [4. ed.] / elaboração Fátima Ali Abdalah Abdel Cader Nascimento Universidade Federal de São Carlos - UFSC/SP, prof. Shirley Rodrigues Maia - Associação Educacional para a Múltipla Deficiência - AHIMSA. - Brasília: MEC, Secretaria de Educação Especial, 01-82.

CIF (2004) Classificação Internacional de Funcionalidade, Incapacidade e Saúde. Organização Mundial da Saúde. Direção Geral da Saúde. Lisboa, 01-238.

COSTA, Maria da Piedade Resende da. (2013). In.: Marquezine, Maria Cristina et al. Atendimento Educacional Especializado. Marília: ABBE: Marquezine\& Manzini, 187-205.

GODOY, Shirley Alves. Guia-intérprete ou instrutor mediador:percepções de uma professora especialista. (2014). In.: VI Congresso Brasileiro de Educação Especial - VI CBEE, IX Encontro Nacional dos Pesquisadores da Educação Especial - IX ENPEE, 2014. Anais do VI Congresso Brasileiro de Educação Especial, 1-15.

GOMES, Marcia Regina. (2016).Surdocegueira: algumas considerações para a educação. Revista Fórum, 26-38.

GRUPO BRASIL de Apoio ao Surdocego e ao Múltiplo Deficiente Sensorial. (2005). Surdocego pós-linguístico. Orgs. Watanabe, Dalva R., Giacomini, Lilia, Maia Shirley R e Serpa Ximena. São Paulo: Ciclo Press Gráfica \& Fotolito. 


\section{Macrothink}

GRUPO BRASIL. (2012). Projeto Pontes e Travessias: Formação de Guia-Intérprete. Centro de Recursos nas áreas da Surdocegueira e Deficiência Múltipla Sensorial - Programa da Ahimsa Associação Educação para Múltipla Deficiência. Projeto assistido pelo Programa Hilton Perkins da Escola Perkins para Cegos, Watertown, Mass. U.S.A. O Programa Hilton Perkins é subvencionado por uma doação da Fundação Conrad N. Hilton, de Reno, Nevada U.S.A. Projeto Ahimsa/Hilton Perkins, 01-91.

LAGATI, S. (2002). Deaf-Blind or Deafblind International Perspectives on Terminology.1995 Tradução: Laura L. M. Anccilotto. São Paulo: Projeto Ahimsa/Hilton Perkins.

MASINI, Elcie F. Salzano. (2002). Do sentido... pelos sentidos... para o sentido... Niterói: Intertexto; São Paulo: Vetor, 13-303.

WATANABE, Dalva Rosa. (2012). Profissionais que atuam e apoiam a inclusão de pessoas com deficiência: Guia-intérprete, Instrutor Mediador, Tradutor Intérprete de Língua de Sinais e Cuidador. Grupo Brasil de Apoio ao Surdocego e ao Múltiplo Deficiente Sensorial, 01-06.

\section{Copyright Disclaimer}

Copyright for this article is retained by the author(s), with first publication rights granted to the journal.

This is an open-access article distributed under the terms and conditions of the Creative Commons Attribution license (http://creativecommons.org/licenses/by/3.0/). 